\title{
Economics of Renewable Energy for Water Desalination in Developing Countries
}

\author{
Enas R. Shouman $^{1, *}$ M.H. Sorour ${ }^{2}$ and A.G. Abulnour ${ }^{2}$ \\ ${ }^{I}$ Information Systems Department, National Research Center, Dokki, Giza, Egypt \\ ${ }^{2}$ Chemical Engineering and Pilot Plant Department, National Research Center, Dokki, Giza, Egypt
}

Received 27 November 2015; Accepted 29 December 2015

\begin{abstract}
The aim of this study is to investigate the economics of renewable energy- powered desalination, as applied to water supply for remote coastal and desert communities in developing countries.

In this paper, the issue of integration of desalination technologies and renewable energy from specified sources is addressed. The features of Photovoltaic (PV) system combined with reverse osmosis desalination technology, which represents the most commonly applied integration between renewable energy and desalination technology, are analyzed. Further, a case study for conceptual seawater reverse osmosis (SW-RO) desalination plant with $1000 \mathrm{~m}^{3} / \mathrm{d}$ capacity is presented, based on PV and conventional generators powered with fossil fuel to be installed in a remote coastal area in Egypt, as a typical developing country.

The estimated water cost for desalination with PV/ SW-RO system is about $\$ 1.25 \mathrm{~m}^{3}$, while ranging between $\$ 1.22-1.59$ for SW-RO powered with conventional generator powered with fossil fuel.

Analysis of the economical, technical and environmental factors depicts the merits of using large scale integrated PV/RO system as an economically feasible water supply relying upon a renewable energy source.
\end{abstract}

Renewable energy powered desalination-Photovoltaic (PV) -Desalination- Reverse Osmosis (RO) - Economics- Developing countries.

\section{Introduction}

There is a worldwide trend to intensify the use of desalination to reduce current or future water shortage. Over a billion people worldwide lack access to sufficient water of good quality (Francisco Diogo ,et.al, 2014). Most of these people live in Asia and Africa. The growing population and steady increase in the living standards lead to increasing the specific water consumption per capita. A considerable increase in the world population (over the next decade) will be concentrated mainly in most of the developing countries and particularly in Africa, causing severe water shortages (FAOSTAT Database, June 2000). As a result, $40 \%$ of the world population is facing serious water shortage, mostly in remote rural areas and expanding urban areas (UNEP, 2003). According to a market research, a predicted average 3\% increase in annual demand for fresh water would require an annual investment of about $\$ 500$ billion in water supply (UNEP, 2008).

Renewable energies (RES) are expected to have a promising future and an important role in the domain of brackish and seawater desalination in developing countries. Recently, there are intensive endeavors to develop and install large-scale desalination plants, mainly powered by renewable energy sources, for low-density population areas deprived of electrical power grid connections. The cheap fresh water may be produced from brackish or seawater by using solar panels and other renewable energy technologies.

\footnotetext{
*E-mail address: Shouman28@hotmail.com ISSN: 1791-2377 @ 2015 Kavala Institute of Technology. All rights reserved.
}

The development of these technologies will be important for developing countries that are currently suffering from water shortage and do not have access to economical conventional energy resources to implement desalination systems. In addition, due to the fact that fossil fuel prices are characterized by high variability and a trend upwards, the use of renewable energies allows for saving fossil fuels and hence reducing risks related to energy price escalation along the whole desalination plants life cycle.

Generally, integration with renewable energy sources can be achieved by direct use the heat or mechanical energy ,or by generating electricity. Numerous efforts have been carried out throughout the world to find suitable coupling between desalination and RES. The suitability of a given renewable energy source for powering a specific desalting system depends on its type and magnitude of obtained energy. Different combinations between renewable energy sources and desalination technologies can be applied (Rodriguez- Girones, et.al, June 10-12, (1996), (S. Edward, 2006), (Tzen E., 2005), (Voivontas D., 1999).

In this paper, the issue of technology integration is addressed. Special emphasis is focused upon PV system and SW-RO desalination. Further, a case study is presented for SW-RO desalination powered with PV system or conventional electricity-generator. Technical, economical and environmental merits are elucidated for applying desalination with relatively large scale PV/SW-RO

\section{Material and Methods}


The present study was conducted in the National Research center, Egypt. The approach to conduct the study involves the following:

- Identification of applicable techniques for combined renewable energy/ desalination system

- Technical, economic and environmental assessment of the viable option for the water supply of fresh water for remote coastal communities, a typical developing country

- Investigating a conceptual case study for application of renewable energy- desalination in Egypt, as a typical developing country.

\section{Result and discussion}

3.1 Desalination - Renewable energy (RE) integration Renewable energy/desalination options may be outlined s follows:

- Solar energy options, including solar photovoltaic or solar thermal options .PV could be integrated with RO desalination. Solar thermal systems could be coupled with $\mathrm{RO}$ and mechanical vapor compression desalination systems.

- Wind energy ,through direct use of mechanical shaft power or electricity generation could be integrated with $\mathrm{RO}$, mechanical vapor compression and electrodialysis.

- Geothermal energy, through direct use of thermal energy could be used with multistage flash, multiple effect distillation and thermo vapor compression .Electricity generation could be applied with RO, electrodialysis and mechanical vapor compression.

- Combined wind, with solar or geothermal energy could be also integrated with thermal and membrane desalination.

The current dominant renewable energy source for desalination is solar photovoltaic (PV), which represent about $43 \%$ of the existing capacity, followed by solar thermal and wind energy (European Union, 2008). The right combination of a renewable energy source with a desalination technology can be the key to match both power and water demand economically, efficiently and in an environmentally friendly way.

In conclusion, desalination based on the use of renewable energy sources can provide a sustainable technology to produce fresh water. It is expected to become economically attractive as the costs of renewable technologies continue to decrease. Applying locally available renewable energy resources for desalination is likely to be feasible, particularly in remote regions deprived of efficient electricity supply. Although, the present deployment of renewable-based desalination is less than $1 \%$ of desalination capacity based on conventional fossil fuels (L. Garcia-Rodriguez, 2003), it is anticipated that much higher contribution of the desalination/ RES in the near future will be achieved.

\subsection{Economics of desalination/renewable energy systems} The cost of desalination is largely dominated by the energy cost. Therefore, the economical feasibility of desalination depends strongly on local availability and cost of energy.
The most commonly used technologies are reverse osmosis (RO), multistage flash (MSF) and multi-effect distillation (MED) and electrodialysis (ED). The percentages of the global capacity according to technology are $60 \%, 27 \%, 9 \%$, and $4 \%$ for RO,MSF,MED and ED, respectively (United Nations, (2009). Low capacity, solar still is reported to produce water at cost ranging from $\$ 2.4$ to $\$ 20 / \mathrm{m}^{3}$ (Washington DC, 2004), (A.A.Madani, G.M.Zaki, 1995), (Bouchekima B., et. al, 1998). Recent improvements in solar distillation technology makes it an ideal technology for some remote isolated areas (Fath H.E.S. (1997).

The dominant competing technology is reverse osmosis (RO), (Komgold E. et.al, (1996). The reported production cost range for large scale conventional desalination is $\$ 1$ $\$ 2 / \mathrm{m}^{3}$ (Komgold E., et.al, 1996). RO has lower energy consumption when compared to MSF and MED (Madani A.A., et.al, 1995).

Costs breakdown for SW-RO desalination showed that energy represents about $43 \%$ of the total water production cost, compared to $59 \%$ for large-scale thermal desalination plant (Washington DC, 2004).

Typical reported capacities applied and costs of desalted fresh water from most common desalination processes based on renewable energy are shown in Table (1) (Miller J. E., 2003). Most of such technologies demonstrated rapid decrease of renewable energy costs and technical advances.

Table 1. Typical capacities and costs for most common options of solar and wind seawater desalination (Miller J. E., 2003).

\begin{tabular}{|c|c|c|c|}
\hline Option & $\begin{array}{c}\text { Capacity } \\
\mathrm{m}^{3} / \mathrm{d}\end{array}$ & $\begin{array}{l}\text { Energy } \\
\text { Consumption } \\
\left(\mathrm{kWh} / \mathrm{m}^{3}\right)\end{array}$ & $\begin{array}{l}\text { Water Cost } \\
\left(\$ / \mathbf{m}^{3}\right)\end{array}$ \\
\hline Solar stills & $<0.1$ & - & $1.3-6.5$ \\
\hline $\begin{array}{l}\text { Solar-Multiple Effect } \\
\text { Humidification }\end{array}$ & $1-100$ & $\begin{array}{l}\text { Thermal: } 100 \\
\text { Electrical: } 1.5\end{array}$ & $2.6-6.5$ \\
\hline $\begin{array}{l}\text { Solar/CSP*-Multiple } \\
\text { Effect Distillation }\end{array}$ & $>5,000$ & $\begin{array}{l}\text { Thermal: } 60- \\
70 \\
\text { Electrical: } \\
1.5-2\end{array}$ & $2.3-2.9$ \\
\hline $\begin{array}{l}\text { Photovoltaic -Reverse } \\
\text { Osmosis }\end{array}$ & $<100$ & Electrical: 4-5 & $11.7-15.6$ \\
\hline $\begin{array}{l}\text { Wind-Reverse } \\
\text { Osmosis }\end{array}$ & $50-2,000$ & $\begin{array}{l}\text { Electrical } \\
4-5\end{array}$ & $\begin{array}{l}6.5- \\
9.5(\text { capacity } \\
\left.<100 \mathrm{~m}^{3} / \mathrm{d}\right) \\
6.5-9.1 \\
2-5.2(\text { capacity } \\
\left.1000 \mathrm{~m}^{3} / \mathrm{d}\right)\end{array}$ \\
\hline $\begin{array}{l}\text { Wind-Mechanical } \\
\text { Vapor Compression }\end{array}$ & $<100$ & $\begin{array}{l}\text { Electrical } \\
11-14\end{array}$ & $5.2-7.8$ \\
\hline
\end{tabular}

The future expected electricity costs beyond year 2020 for the most common solar systems have been reported to be $\$ 0.04-0.1 / \mathrm{kwh}$ and about $0.04 / \mathrm{kwh}$ for solar thermal and photovoltaic systems, respectively for an annual solar energy isolation of $2500 \mathrm{kw} / \mathrm{m}^{2}$.

The optimistic forecast of electricity cost of photovoltaic system, especially in countries with high solar energy isolation, as in the case of Egypt and many other developing countries, will lead to better economics of PV-RO desalination.

\subsection{Case study}


Seawater reverse osmosis (SW-RO) desalination plant $\left(1000 \mathrm{~m}^{3} / \mathrm{d}\right)$ powered with photovoltaic (PV) or conventional diesel electricity generation system (DG). In this section, a conceptual case study for desalination plant based on RO technology, powered with renewable energy PV system is presented. The choice of RO and PV technology is based on dominant application and promising future of such technology. The plant is designed for Egypt, as a typical developing country, with excellent high average annual solar energy isolation of $2500 \mathrm{kwh} / \mathrm{m}^{2}$ (Enas $\mathrm{R}$. Shouman and Khattab N.M., 2015). The present state of the art in both RO and PV-systems and cost indicators are applied based on international up-dated published data and national experience (Enas R. Shouman and Khattab N.M., 2015), (Franz Trieb, 2002).

The objective of this case study is to elucidate the technical, economical and environmental merits of applying SW-RO with relatively high capacity powered with PV system, as compared to conventional powering with diesel generator (DG), conventionally used in remote coastal areas for supplying electrical power. Fig.1 represents a schematic for the SW-RO desalination plant with PV and diesel powering options.

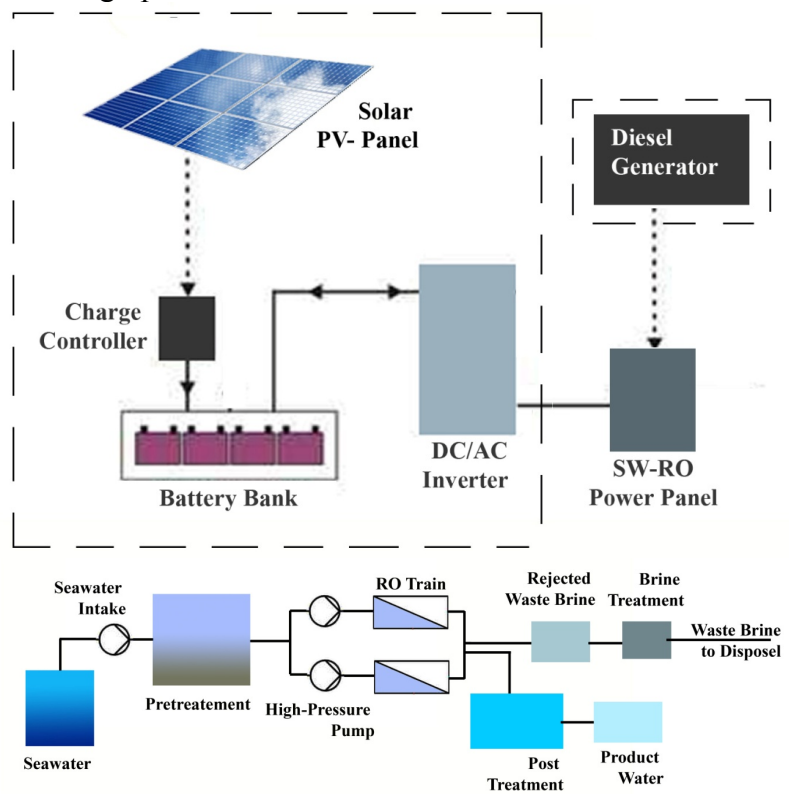

Fig.1 A schematic for the SW-RO desalination plant with PV and diesel power options

Table (2) illustrates the main technical features of the system, including SW- RO and power generation systems (PV or DG), as well as basis of cost estimates

Table 2. Technical and economic features of SW-RO desalination plant $1000 \mathrm{~m} 3 / \mathrm{d}$

\begin{tabular}{|c|c|c|c|}
\hline Item & SW-RO system & DG system & $\begin{array}{c}\text { PV- Power } \\
\text { system }\end{array}$ \\
\hline $\begin{array}{l}\text { System } \\
\text { components }\end{array}$ & $\begin{array}{l}\text { Raw seawater } \\
\text { intake/ rejected } \\
\text { brine outfall } \\
\text { Seawater } \\
\text { pretreatment, } \\
\text { including } \\
\text { chlorination for } \\
\text { algae removal, } \\
\text { dechlorination to } \\
\text { remove excess } \\
\text { active chlorine, } \\
\text { pH- adjustment, } \\
\text { dual media filters }\end{array}$ & $\begin{array}{l}2 \text { diesel } \\
\text { generator, } \\
\text { each } 300 \\
\text { KVA- } \\
\text { capacity } \\
\text { Diesel } \\
\text { fuel } \\
\text { storage } \\
\text { and } \\
\text { handling } \\
\text { system } \\
\text { Power } \\
\text { sunnlv. }\end{array}$ & $\begin{array}{l}\text { PV- } \\
\text { panels, } \\
\text { for } \\
\text { average } \\
\text { power } / 24 \\
\text { hrs of } 250 \\
\mathrm{~kW} \\
\text { Storage } \\
\text { system } \\
\text { including } \\
\text { batteries, } \\
\text { charge } \\
\text { controller }\end{array}$ \\
\hline
\end{tabular}

\begin{tabular}{|c|c|c|c|}
\hline & $\begin{array}{l}\text { and fine filters } \\
\text { RO system } \\
\text { comprising } 2 \text { trains } \\
\text { each } 500 \mathrm{~m}^{3} / \mathrm{d} \\
\text { including high press } \\
\text { pumps with energy } \\
\text { recovery system, } \\
\text { membrane modules } \\
\text { arranged on skid, } \\
\text { piping fittings and } \\
\text { valves, } \\
\text { instrumentation and } \\
\text { measurements } \\
\text { Post treatment } \\
\text { including } \\
\text { Operation and } \\
\text { control panels } \\
\text { Building \& site } \\
\text { infrastructure }\end{array}$ & $\begin{array}{l}\text { Operation } \\
\text { and } \\
\text { control } \\
\text { panel }\end{array}$ & $\begin{array}{l}\text { and } \\
\text { accessori } \\
\text { es. } \\
\text { O } \mathrm{DC} / \mathrm{AC} \\
\text { inverter } \\
\text { Operation } \\
\text { and } \\
\text { control } \\
\text { panel }\end{array}$ \\
\hline $\begin{array}{l}\text { Basic } \\
\text { Process } \\
\text { design }\end{array}$ & $\begin{array}{l}\text { Seawater salinity: } \\
35000 \mathrm{mg} / \mathrm{l} \\
\text { Production water } \\
\text { salinity : } 300 \text { - } \\
\text { 400mg/ } \\
\text { Modules: spiral } \\
\text { wound SW/RO } \\
\text { membrane } \\
\text { Operating } \\
\text { pressure: } 65 \\
\text { Recovery: } 40 \% \\
\text { Average daily } \\
\text { production hours } 20 \\
\text { hr, } \\
\text { Average yearly } \\
\text { working days } \\
\text { 300d/yr } \\
\text { Average power } \\
\text { consumption :5 } \\
\text { kWh/m } 3\end{array}$ & $\begin{array}{l}\text { Fuel, } \\
\text { Diesel } \\
\text { Fuel } \\
\text { Fuel } \\
\text { consumpti } \\
\text { on: } 0.31 / \\
\text { kWh } \\
\text { Power } \\
\text { output: } \\
\text { AC, } 3 \\
\text { phase, } \\
380 \mathrm{~V}, \\
50 \mathrm{H} 2\end{array}$ & $\begin{array}{l}\text { Average } \\
\text { annual solar } \\
\text { irradiation } \\
2500 \\
\mathrm{kWh} / \mathrm{m}^{2}\end{array}$ \\
\hline $\begin{array}{l}\text { Cost } \\
\text { estimate } \\
\text { basis } \\
\text { 1-Capital } \\
\text { cost } \\
\\
2- \\
\text { Depreciation }\end{array}$ & $\begin{array}{l}\text { average market price } \\
\text { of } \$ 1500 \mathrm{~m}^{3} / \mathrm{d} \\
\text { capacity } \\
\text { Plant life time of } \\
\text { 15years }\end{array}$ & $\begin{array}{l}\text { Based on } \\
\text { average } \\
\text { market prices } \\
\text { System life } \\
\text { time of } 10 \\
\text { years }\end{array}$ & $\begin{array}{l}\text { Average } \\
\text { market price } \\
\text { of } \\
\$ 8000 / \mathrm{kW} \\
\text { System life } \\
\text { time of } 20 \\
\text { years }\end{array}$ \\
\hline $\begin{array}{l}\text { 3- Operating } \\
\text { cost }(O \& M)\end{array}$ & $\begin{array}{l}\text { Maintenance } 3 \% \text { of } \\
\text { capital cost } \\
\text { Labor } \$ 0.05 / \mathrm{m}^{3} \\
\text { Chemical } \$ 0.03 / \mathrm{m}^{3}\end{array}$ & $\begin{array}{l}\text { Fuel cost } \\
\text { variable } \\
\text { according to } \\
\text { oil price } \\
\text { (range } \$ 0.2- \\
0.5 / 1 \text { ) } \\
\text { Maintenance } \\
5 \% \text { of } \\
\text { capital cost } \\
\text { Labor } \$ \\
15000 / y r \\
\text { Diesel fuel } \\
\text { price } \$ 0.2- \\
0.5 / 1\end{array}$ & $\begin{array}{l}\text { Maintenance } \\
3 \% \text { of } \\
\text { capital cost } \\
\text { Labor \$ } \\
15000 / y r \\
-\end{array}$ \\
\hline
\end{tabular}

Table (3) represents the estimated capital, annual operation and maintenance (O\&M), depreciation, annual operation cost of the sub-system and the integrated system as well as unit cost of water produced and electricity generated. As indicated from table (4), the capital cost of the integrated RO- PV system is 1.75 times than of RO-DG. The cost of water for RO- PV system is about $\$ 1.25 / \mathrm{m}^{3}$, while for RO-DG, it ranges between $\$ 1.22-1.59 / \mathrm{m}^{3}$ depending on fuel price. 
Table 3. Summary of cost estimates for RO-PV \& diesel powered desalination plant $\left(1000 \mathrm{~m}^{3} / \mathrm{d}\right)$

\begin{tabular}{|c|c|c|c|c|c|}
\hline $\begin{array}{l}\text { Cost items for } \\
\text { RO-PV \& } \\
\text { Diesel } \\
\text { Desalination } \\
\text { plants }\end{array}$ & RO & $\begin{array}{l}\text { PV- } \\
\text { Power } \\
\text { system }\end{array}$ & $\begin{array}{l}\text { (DG) } \\
\text { Diesel } \\
- \\
\text { Power }\end{array}$ & $\begin{array}{l}\text { RO } \\
+ \\
\text { PV }\end{array}$ & $\begin{array}{l}\text { RO } \\
+ \\
\text { DG }\end{array}$ \\
\hline $\begin{array}{l}\text { Capital } \\
\text { Investment } \\
(\$ 1000) \\
\text { Annual O\&M } \\
(\$ 1000)\end{array}$ & 1500 & 2000 & 500 & 3500 & 2000 \\
\hline - Membrane & 30 & - & - & 30 & 30 \\
\hline replacement & 45 & 60 & 25 & 105 & 70 \\
\hline - Maintenance & 15 & 15 & 15 & 30 & 30 \\
\hline - Labor & 9 & - & & 9 & 9 \\
\hline $\begin{array}{l}\text { - Chemicals } \\
\text { - Fuel price } \\
\$ 0.2-\$ 0.5 / 1\end{array}$ & & - & $\begin{array}{l}75- \\
187.5\end{array}$ & & $\begin{array}{l}75- \\
187.5\end{array}$ \\
\hline $\begin{array}{l}\text { Total annual } \\
(\text { O\&M) }\end{array}$ & 99 & 75 & $\begin{array}{l}115- \\
227.5\end{array}$ & 174 & $\begin{array}{l}214- \\
326.5\end{array}$ \\
\hline $\begin{array}{l}\text { Annual } \\
\text { Depreciation }\end{array}$ & 100 & 100 & 50 & 200 & 150 \\
\hline $\begin{array}{l}\text { Total Annual } \\
\text { cost }\end{array}$ & 199 & 175 & $\begin{array}{l}165- \\
277.5\end{array}$ & 374 & $\begin{array}{l}364- \\
476.5\end{array}$ \\
\hline Unit Cost & $\begin{array}{l}0.67 \\
\$ / \mathrm{m}^{3}\end{array}$ & $\begin{array}{l}0.117 \\
\$ / \\
\mathrm{kWh}\end{array}$ & $\begin{array}{l}0.11- \\
0.185 \\
\$ / k W h\end{array}$ & $\begin{array}{l}1.25 \\
\$ / \mathrm{m}^{3}\end{array}$ & $\begin{array}{l}1.22- \\
1.59 \\
\$ / \mathrm{m}^{3}\end{array}$ \\
\hline
\end{tabular}

Table (4) depicts a qualitative comparison of the economical, technical and environmental factors of the two applied options

Table 4. Qualitative comparison of economic, technical \& environmental factors for SW-RO desalination powered with PV \& DG options.

\begin{tabular}{|c|c|c|c|c|}
\hline Item & $\begin{array}{l}\text { RO } \\
+ \text { PV }\end{array}$ & Reason & $\begin{array}{l}\text { RO + } \\
\text { DG }\end{array}$ & Reason \\
\hline \multicolumn{5}{|l|}{$\begin{array}{l}\text { Economic } \\
\text { factors }\end{array}$} \\
\hline $\begin{array}{l}\text { - } \text { Capital } \\
\text { Investment }\end{array}$ & High & $\begin{array}{l}\text { High PV- } \\
\text { system cost }\end{array}$ & Moderate & $\begin{array}{l}\text { DG is much } \\
\text { cheaper than } \\
\text { PV system }\end{array}$ \\
\hline - O\&M & Low & $\begin{array}{l}\text { No fuel is } \\
\text { used }\end{array}$ & Moderate & $\begin{array}{l}\text { Fuel price is } \\
\text { dependent on } \\
\text { oil price } \\
\text { fluctuations. }\end{array}$ \\
\hline $\begin{array}{l}\text { - Improvement } \\
\text { Opportunity }\end{array}$ & High & $\begin{array}{l}\text { Improvement } \\
\text { of PV } \\
\text { system cost } \\
\text { reduction. } \\
\text { Potential } \\
\text { improvement }\end{array}$ & Moderate & $\begin{array}{l}\text { Potential } \\
\text { improvement } \\
\text { in SW-RO } \\
\text { membrane and } \\
\text { power } \\
\text { consumption }\end{array}$ \\
\hline
\end{tabular}

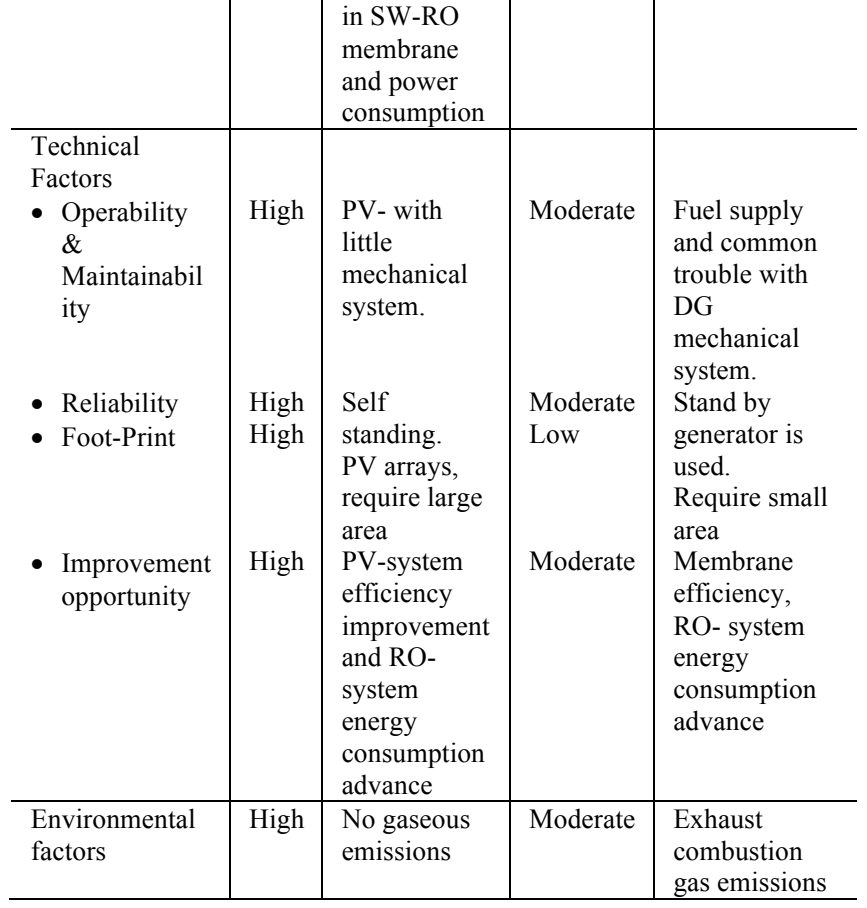

\section{Conclusion}

Desalination represents a potential alternative technology for the efficient production of water from saline water sources at remote coastal and desert areas. The continuous development in improving energy consumption reduction and the improvement in PV-power system efficiency and cost will lead eventually to wide-spread application of the combined RO-PV system as a reliable and sustainable source of fresh water supply in remote areas, deprived from potable water and electricity. The merits of application of the RO-PV system in arid areas in developing countries is much favored by the high solar energy isolation which is double that in many developed countries. According to the presented case study, the cost of producing water for is $\$ 1.213 \mathrm{~m}^{3}$, compared with variable cost of $\$ 1.118-1.555 / \mathrm{m}^{3}$ (according to the fuel price variation). The prospective for cost reduction in RO-PV system is promising in view of progressive development of $\mathrm{PV}$ and $\mathrm{RO}$ systems, and it is expected with scaling up to high capacities, the economics of water production shall improve.

Besides, the technical and economical feature, the RO-PV system is characterized by being friend to the environment (with no gaseous emission).

\section{References}

1. Bouchekima B., Gros B., Oahes R., Diboun M., 1998, Performance study of the capillary film solar distiller. Desalination 116, 185-192 pp.

2. Edward S., 7 February 2006, The potential for wind- powered desalination in water- scarce countries, Master of Arts in Law and Diplomacy Thesis. http://fletcher.tufts.edu

3. Enas R. Shouman and Khattab N.M., 2015, Future economic of concentrating solar power(CSP) for electricity generation in Egypt, Renewable and Sustainable Energy Reviews 41, 1119-1127 pp

4. European Union, 2008, ADIRA Handbook, A guide to desalination system concepts, Euro-Mediterranean Regional Programme for Water Management (MEDA), ISBN978-975-561-311-6. http://wrri.nmsu.edu/conf/conf11/2008_adira_handbook.pdf
5. Fath H.E.S., 1997, High performance of a simple design, two effects, solar distillation unit. Energy Conversion and Management 38, 1895-1905 pp.

6. Food and Agriculture Organization of the United Nations, June 2000, The FAOSTAT Database, Population: annual time series, Rome.

7. Francisco Diogo Abreu Santos Moniz Azevedo, 2014, Renewable Energy Powered Desalination Systems: Technologies and Market Analysis, $68 \mathrm{pp}$.

8. Franz Trieb, Joachim Nitsch, Stefan Kronshage, Christoph Schillings, Lars-Arvid Brischke, Gerhard Kniesb, Czisch G., 2002, Combined solar power and desalination plants for the Mediterranean region - sustainable energy supply using large-scale solar thermal power plants, Desalination 153, 39-46 pp.

9. Garcia-Rodriguez L., 2003, Renewable energy applications in desalination: state of the art. Solar Energv 381-393 pp. 
10. Komgold E., Korin E., Ladizhensky I., 1996, Water desalination by evaporation with hollow fiber membranes, Desalination 107, 121$129 \mathrm{pp}$.

11. Madani A.A., Zaki G.M., (1995), Yield of stills with porous basins. Applied Energy, 273-281pp.

12. Miller J. E. 2003, Review of Water Resources and Desalination Technologies. Sandia National Laboratories, Albuquerque, NM. (2004) 49 pp. http://www.sandia.gov/water/docs/ MillerSAND2003_0800.pdf

13. Washington DC, 2004, Review of the Desalination and Water Purification Technology Roadmap. National Research Council; The National Academies Press,

14. Rodriguez- Girones, M. Rodriguez, J. Perez, J. Veza, June 10-12, 1996, A systematic approach to desalination powered by solar, wind and geothermal energy sources. Proceedings Mediterranean conference on renewable energy sources for water production, Santorini, Greece, 20-25 pp.

15. Tzen E., 2005, Successful Desalination RES Plants Worldwide (Hammamet, Tunisia: Centre for Renewable Energy Sources) < www.adu-res.org/pdf/CRES.pdf>

16. UNEP (United Nations Environment Programme), 2003, Key Facts about Water. www.unep.org/wed/2003/keyfacts (accessed January $15,2006)$

17. UNEP, 2008, Vital Water Graphics: An Overview of the State of the World's Fresh and Marine Waters - 2nd Edition.

18. United Nations, 2009, Economic and Social Commission for Western Asia (ESCWA). ESCWA Water Development Report 3: Role of Desalination in addressing water scarcity. United Nations Publications.

19. Voivontas D., Yannopoulos K., Rados K., Zervos A. and Assimacopoulos D., 1999, Market potential of renewable energy powered desalination systems in Greece, Desalination, 159-172 pp. 